\title{
Sheldon-Hall syndrome
}

\author{
INSERM
}

\section{Source}

INSERM. (1999). Orphanet: an online rare disease and orphan drug data base. Sheldon-

Hall syndrome. ORPHA:1147

Sheldon-Hall syndrome (SHS) is a rare multiple congenital contracture syndrome characterized by contractures of the distal joints of the limbs, triangular face, downslanting palpebral fissures, small mouth, and high arched palate. 